\title{
Meclis'te Grubu Bulunan Partilerin, 2015 Genel Seçimlerinde, Gazetelerde Çıkan Miting Haberlerinin İçerik Çözümlemesi
}

\author{
Murat Sezgina*, Semih Gökçeb \\ aUşak Üniversitesi, İletişim Fakültesi, Uşak \\ ${ }^{b}$ Uşak Üniversitesi Sosyal Bilimler Enstitüsü, Uşak
}

\section{Öz}

Günümüzde yasama, yargı ve yürütmeden sonra dördüncü gü̧̈ olarak medya görülmektedir. Haberleri veriş şekliyle, konuları ele alı̧̧ biçimiyle, gündemi belirleme gücüyle medya hep tartışılmıştır. Ülkemizin demokrasi tarihine bakıldığında, medya; olayları, durumları abartmada sayısız örnekler vermiştir. Herhangi bir vasfi olmayan köşe yorumcularıyla kamuoyunu oluşturma, yönlendirme çabası içindedir. Ayrıca liberal kapitalist düzende medya büyük holdinglerin yatırım aracına dönüşmüştür. Bugün Türk medyasına baktığımızda Türkiye'nin en önemli holdingleri, Türkiye'nin en önemli gazetelerine, televizyonlarına sahiptir. Bu sahipliklerini her geçen gün pekiştirmektedir. Birçok sektöre yatırım yapan, devlet ihalelerine giren bu holdingler haliyle belli siyasal gruplarla çıkar ilişkisine girmesi kaçınılmazdır. İktidarlarla yakın ilişki içine girmesi veya başka güçlerin iktidara gelmesinde daha büyük çıkar sağlayacak olması dolaylı veya direkt olarak siyasi aktörlere destek olması her zaman tartışılmaktadır. Bu tartışmalar medyanın gücüne güç katmaktadır. Bu çalışmayla 2015 Genel Seçimleri öncesi dört farklı bakış açısına sahip Hürriyet, Cumhuriyet, Ortadoğu ve Yeni Şafak gazetelerinin, mecliste temsil edilen dört farkl siyasi partiye (CHP, MHP, AKP ve HDP) yaklaşımının fotoğrafı çekilmeye çalışılmıştır.

Anahtar kelimeler: Siyasal İletişim, Seçim Mitingleri, 2015 Genel Seçimleri, Mitingler, İçerik analizi

\section{Content Analysis of Rally News of Political Parties in the Assembly in the 2015 General Elections}

\begin{abstract}
Today, media is seen as the fourth force after legislation, justice and executive. Media has always been argued with its presentation of news, its method to approach to topics and its power to determine the agenda. Looking to our democracy history, medya has given countless example in exaggerating the situations. It tries to render and direct the public opinion. Moreover, in liberal capitalist system, media has transformed into investment tool of big holdings. Today, looking to Turkish media, it is seen that the most important holdings of Turkey have the most important newspapers and televisions. They reinforce their ownership day by day. These holdings, which invest on several sectors and bid in a state tender, be in a relationship based on interests with some political groups unavoidably. It's being in a close relationship with authorities or it's getting more benefit from another authority's coming to power and it's supporting political actors directly or indirectly has always been argued. These arguments strengthen the media. Via this work, before general elections of 2015, it is aimed to take a picture of the approach of Hürriyet, Cumhuriyet, Ortadoğu and Yenişafak, which are four newspapers of four different political aspect to the four different political parties which are represented in national assembly.
\end{abstract}

Keywords: Political Communications, Election Rallies, 2015 General Elections, Rallies, Content Analysis 


\section{GíRiş}

İçerik analizleri 20. Yüzyılda sosyoloji, psikoloji, iletişim bilimleri, tarih bilimlerinde yani toplumbilimlerinde kullanılmıştır. Özellikle de, daha çok kitle iletişimi araştırmalarında kullanılmıştır.

İçerik analiziyle ortaya konan iletişim materyalleri incelenir. Mevcut veriler özetlenir, standardize edilir, karşılaştırma ya da başka bir biçime dönüştürme gerçekleştirilir. Çıkan sonuçlar yorumlanır.

\section{1. İçerik Analizinin Tarihsel Süreci}

İçerik analizi 16. yüzyılda gazeteler üzerinde yapılmıştır. Daha çok dini nedenlerle yapılmıştır. Gazetelerde dinsel, ilahi mesajlar ne ölçüde kullanıldığını öğrenmek amaçlı içerik analizine başvurulmuştur.

İçerik çözümlemesi 20. Yüzyılın başında, Columbia Gazetecilik Okulu'nun, gazetelerin nicel analizine ilişkin çalışmalarıyla başlamıştır. İçerik çözümlemesinde çalışan ilk önemli kişi H. Lasswell'dir (Aziz; 2003: 120).

Birinci ve İkinci Dünya Savaşları, propaganda tekniklerinin önem kazandığı dönemlerdir. I. ve II. Dünya Savaşları sırasında ve II. Dünya Savaşı'ndan sonraki soğuk savaş sırasında; propaganda tekniklerini, iletişim materyallerini ve içeriğini incelemek önem kazanmıştır. Bilgisayar teknolojisindeki gelişmeler içerik çözümlemesinin ayrıntılı ve kapsamlı olarak yapılmasına yardımcı olmaktadır.

İçerik çözümlemesinin Türkiye'deki durumu ise; kitle iletişim araçlarının kullanım geçmişinin çok fazla olmaması olumsuz etkilemiştir. 1960'l yıllardan bu yana yapılan toplumsal bilim araştırmalarının bazılarında içerik çözümlemesi yöntemine benzer yöntemler kullanılmıştır. Ancak bu batının kullanıldığı anlamda değildir.

Türkiye'deki en eski içerik çözümlemesi Hürriyet Gazetesi ile ilgili çözümlemedir. Fransız Araştırmacı Jacques Kayser tarafından 1951 yılında, 17 ülke gazetesinin 1 haftalık yayınları alınarak karşılaştırmalı olarak yapılan bu araştırmada, Türkiye'den Hürriyet Gazetesi alınmıştır. Araştırma daha çok fiziksel birimleştirmeye göre yapılmış, daha sonra gazetede yer alan konuların kapsadıkları alan ölçülmüştür. Şuanda Türkiye'de, birçok sosyal bilimlerde içerik analizi yöntemi kullanılmaktadır (Aziz; 2003: 134-135).

\section{2. İçerik Çözümlemesi Tanımları}

İçerik çözümlemesi, çözümleme yöntemidir. Ortaya konu olan iletişim materyalleri incelenir. Nitel veriler, nicel terimlerle ifade edilir. Hali hazırda bulunan veriler içerik çözümlemesi ile özetlenebilir, karşılaştırılabilir.

İçerik çözümlemesi, araştırılan içeriğin objektif ve nicel olarak farklı yönleri ayrıntılı ele alarak aktaran tekniktir. İçerik çözümlemesi; bir kapsam çerçevesinde farklı tutumların, ilgilerin belge ya da bir mesajın içeriklerini değerlendirmek için kullanılan işlemdir. 
İçerik çözümlemesinde farklı araştırmacıların, aynı materyallerle aynı sonuçlara ulaşması nesnelliği ifade eder. Araştırmacılar her araştırmada olduğu gibi sistemlilikle üzerinde çalıştığı konunun amaçlarına uygun olan verilerle çözümleme yaparak diğer verilerin ihmal edilmesi önlenir. Her bilimsel araştırmada olduğu gibi genellik olması gerekir. Bunun için aynı ölçütlerin kullanılması gerekmektedir.

\section{3. İçerik Çözümlemesi Türleri}

İçerik çözümlemeleri türlerine göre aşağıdaki gibidir (Aziz; 2003: 122).

\subsection{Pragmatik Çözümleme}

İşaretlerin olabilen nedenlerine ya da etkilerine göre sınıflandırma yöntemidir. Örneğin iletinin verildiği zamanlardaki sıklığı sayarak nasıl bir etkisi olacağını ortaya çıkarılması amacı ile yapılabilir.

\subsection{Anlambilimsel Çözümleme}

Sözcüklerin anlamlarına göre sayma ile ilgili bir çözümleme türüdür. Söz gelişi bir mesajda kaç kez doğrudan ya da dolaylı Atatürk'e atıfta bulunan, örneğin "Ata", "Mustafa Kemal”, "Gazi”, "Ulu Önder" vb. gibi sözcüklerinin geçtiğinin araştırılması, bu tür bir çözümlemeye örnektir.

\section{3. İşaret Aracı Çözümleme}

Bir mesaj içeriğinin, işaretlerin psiko-fiziksel özelliklerine göre sıklığının sayılmasıdır. Örneğin bir mesajda "Avrupa" sözcügünün kaç kez geçtiğinin sayılması gibi.

\section{4. İçerik Çözümlemeleri Uygulamaları}

İçerik çözümlemesinin amacına göre iki ana türü vardır. Bunlar alan incelemeleri ve mesajın anlamının çözümlenmesidir (Aziz; 2003: 123-124).

\subsection{Alan Çözümlemesi}

İletilmek istenen mesajın yer aldığı araca bağlı olarak ölçümlenir. Basılı mesajlarda alan çözümlemeleri "cm." ile görüntülü ve sesli mesajların ölçümlenmesi "zaman" olarak yapılabilmektedir. Örneğin tv reklamlarında birim; dakika, saniyedir. Reklamdaki mesajları ne kadar yer aldığı hususu ancak zaman birimi ile ölçülür.

\subsection{Mesaj Çözümlemesi}

Ölçmek istenilen husus, içerik çözümlemesinin alt türlerini belirler. Örneğin bir tv reklamının içerik çözümlenmesinde reklamda yer alan karakterlerin tutum ve davranışlarının incelenmesi yapılabileceği gibi, bunların sözel iletişimde kullandıkları sözcüklerin sıklığı ile ölçülebilir.

\section{5. İçerik Çözümleme Tekniğinin Öğeleri}

Aziz'e göre (2003) içerik çözümleme öğeleri bir anlamda içerik çözümlemesinin yapımındaki aşamaları da içermektedir. Bu öğelerin önemli bir kısmı salt bu yönteme özgü değildir. Toplum bilimlerin diğer gözlem tekniklerinde de bulunan ya da 
kullanılan öğeler, özellikler, aşamalardır. Bu aşamalar; veri toplama, birimleştirme, örneklem, kayıtlama yönergesi, çözümleme, çıkarsama yapma ve çalışmanın raporlaştırılmasıdır.

\subsection{Veri Toplama Aşaması}

Yapılan araştırmada veriler, farklı kaynaklardan çeşitli yollarla elde edilir. Bu kaynak ve yolların seçimi verinin özelliğine, veri kaynağının durumuna, araştırmacının imkânına bağlıdır. Verilerden birçoğu ölçme teknikleriyle elde edilir. Test, ölçme teknikleri arasında en çok başvurulandır. Testler yazılı ve sözlü olabilir (Kaptan, 1982, Akt Balc1, 2011: 149).

Veriler, belli konudaki gerçeklerin sembolik ifadeleridir. Veriler işlenmemiş kanıtlardır; ekonomik bir değere henüz dönüşmemiş ve insan davranışı üzerinde etkisi olmayan dayanaklardır. Araştırmada veriler araştırma amacını gerçekleştirmek için gerekli olan kanıtlardır. Doğaldır ki bu kanıtların ne tür olacağı, nereden sağlanacağı araştırma araçlarla elde edilmesi bu durumu değiştirmez. Bu yüzden veriler gözlenen ve kaydedilen şeylerdir denebilir (Balc1, 2011: 149). Veri; yazı, kitap, gazete, dergi, film, tiyatro, TV dramaları, reklamlar, tarihsel belgeler, siyasal konuşmalar, mülakat veriye örnek olabilir.

\subsection{Birimleştirme}

Birimleştirme ampirik gerçeklerin, araştırmanın amaçlarına ve bunlara uygun olarak alınan gözlem tekniğinin bir işlevi olarak tanımlanmaktadır. Birimleştirme olmadan nitelikle çözümlemeden söz edilemez. Birimleştirme, birimlerin tanımlanması, sınırların ayrılması ve sonraki çözümleme için kimlik kazandırılması ile ilgilidir (Aziz, 2003: 125).

Fiziksel birimler; çözümlenen içeriğin bulunduğu aracın fiziksel olarak incelenmesidir. Kapsadığı alan, uzunluk; zaman olarak saat ve dakikanın ölçümlenmesidir. Sözel birimler; görsel ve işitsel kitle iletişim araçlarında yayımlanan mesajlardaki sözlerle, dilbilgisiyle ilgili birimleştirmedir. Gönderim birimleri; belirli olaylara ve durumlara, kişilere, ülkelere ve fikirlere göndermeler yapılarak oluşturulur. Öneri birimler; uzun ve karmaşık bir tümceyle çözümleme yapmak için bu tümceye bazı önermeler yapılabilir. Örneğin; reklamdaki erkek karakteri yardıma gereksinim duyan mi, karar veren mi, yoksa karar alan biri olarak mı tanımladığı araştırmalarda bir takım önermeler yapılabilir. Konu birimleri; folklor çözümlemelerinde kullanılan kaynak dil çok iyi bilinmelidir.

Üç çeşit birimleştirme vardır. Bunlar; örneklem birimleri, kayıtlama birimleri ve sözlere ilişkin birimlerdir (Aziz, 2003: 125). Bunlar aşağıdaki gibidir.

\subsection{1. Örneklem Birimleri}

Gerçek evrenden gözlemlenen, birimlerden bağımsız kısımlardır. Birbirleri ile bağlantısı olmayan birimlerdir. İstatistiksel çözümlemeye uygun değildir. Veri olma özelliği taşır. Örneğin tv programındaki mesajları, izleyiciler beğenerek ya da beğenmeyerek, eleştirerek izler. Bu durum, araştırmacı tarafından konunun farklı 
boyutları göz önünde bulundurularak mesaj incelenir. Mesaj, farklı konulara göre birimleştirilir. Örneğin mesajı dil bilimciler çözümleyecekse, örnek birimler dil ile ilgilidir.

\subsubsection{Kayıtlama Birimleri}

Gerçek hayatı yansıtmayan tv programında bulunan karakterlerin tutum ve davranışları çözümlenecekse daha önce birimlerden bağımsız olarak yapılan örnek birimler yeterli olmayacak, karakterlerin iç etkileşiminin çözülmesi gerekecektir. Kayıtlama birimleri bu tür çözümlemede kullanılır. Her bir örnek birim içerisinde farklı kategorilerde çözümleme yapmaya yarayacak kayıtlama birimleri vardır. Kayıtlama birimleri karmaşık, geniş ve çok zengin olan örneklem birimlerini daha somut, daha dar ve daha işlevsel duruma getirmek amacı ile yapılır.

\subsubsection{Sözlere İlişkin Birimler}

Diğer birimlerin yetersiz olduğunda bu tür birimleştirmeye gidilir. Kayıtlama birimlerinin kapsamında olan simgesel kavramlar, sözler daha dar tanımlama ile çözümlenmek istendiğinde sözlere ilişkin, simgesel birimleştirmeye gidilir. Bunlar birbiriyle çakışan, yinelenen birimlerdir. Sözlere ilişkin birimler bu açıdan alındığında pek çok kayıtlama biriminin içinde de yer alabilir. Örneğin bir gazetede "uykusuzluk" sözcügünün ne kadar sıklıkla yinelendiği, bunun bir tümcede ya da bir paragrafta kaç kez yinelendiğinin ölçümlenmesi için sözlere ilişkin birimleştirme gereklidir. Bu kayıtlama birimlerinin hepsinin ya da bir kısmının içinde yer alabilir.

\section{3. İçerik Çözümlemesinde Örneklem}

İçerik çözümlemesinde kullanılan belli başlı örneklem yöntemlerinin özellikleri rastgele (tesadüfi) örneklem, tabakalı örneklem, dizgeli örneklem, salkım örneklem, değişken olasılıklı örneklem, çok aşamalı örneklem (Aziz, 2003: 129).

Rastgele (tesadüfi) örneklem; bu tür örnekleme elde etmenin gerekliliği evrendeki birimlerin listelenmesidir. Bu tür örneklemede evrendeki her birimin örnekleme seçilmede eşit ve bağımsız olma olasılığı vardır. Yani yansızlık kuralının uygulanabildiği bir örneklemdir (Akhun, 1991, Akt Balcı, 2011: 96). Eşit evrendeki her birimin örnekleme girmede eşit şansının olduğunu ifade eder. Bir birimin örnekleme girmesi diğerlerinin örnekleme seçilmesine hiç bağlı değildir. Açıkça bu iki ilkenin oluşturduğu yansızlık kuralı istenen büyüklükteki her olası örneklemenin, eşit çekilme olasılığının var olduğunu gösterir (Judd ve diğerleri, 1991, Akt Balc1, 2011: 96).

Tabakalı örneklem; evrendeki alt grupların örneklemde temsil edilmelerinin garanti altına alındığı bir örneklemdir. Bunun için de evren önce iki ya da daha çok tabakaya-alt evrene- alt gruba ayrılır. Bu tabakalama tek bir ölçüte göre (örneğin cinsiyete göre, erkek ve kadın tabakaları) ya da iki ya da daha çok ölçütün birleşmesine göre (diyelim ki yaş ve cinsiyete göre, 20 yaşın altındaki erkekler, 20 yaşın üzerindeki erkekler, 20 yaşın altındaki kadınlar, 20 yaşın üzerindeki kadınlar) yapılabilir. Sonra da her tabakadan basit bir yansız örneklem alınır ve alt örneklemler toplam örneklemi elde etmek üzer birleştirilir (Judd ve diğerleri, 1991, Akt Balcı, 2011: 97). Bu yöntemde evren benzer alt evrelere tabakalara ayrıldığından alt evrenlere ait varyansların daha 
küçük olmasına, dolayısıyla daha küçük örneklemlerle daha temsili istatistiklere ulaşılabilir (Akhun, 1991, Akt Balcı, 2011: 97).

Dizgeli örneklem; rastgele örneklemin sistemleştirilmiş halidir. Bu teknikte başlangıç noktasının belirlenmesinden sonra her "N"nin örnekleme alınmasıdır. Herhangi bir araçla başlangıç noktası belirlenir. Zaman dilimi veya periyodlar işin içine girdiğinde zaman dilimlerinin alınması sakıncalar doğurabilir. Her zaman diliminin kendine özgü koşulları vardır. Bu da örneklemi etkilemektedir.

Salkım örneklem; verilerin önceden bilinmediği durumda yapılır. Verilerin bulunabileceği muhtemel gruplar oluşturulur. Hata payı çoktur. Örneğin TV programlarında azınlıkları varlığı hakkındaki araştırmada azınlıklar hakkında veri yoktur.

Değişken olasılıklı örneklem; diğer bir kotalı örneklemdir. Örneklemi oluşturacak gruba dahil olanların sayısı bilinir. Bu yöntemin kullanılması durumunda örnekleme temel alınan ölçütün açıkça belirtilmesi gerek.

Çok aşamalı örneklem; tek örneklem yönteminin değil yerine göre, verilerin dağınıklığa, büyüklüğüne ve elde edilmek istenen bulgularına göre farklı örneklem yöntemleri araştırmanın farklı zamanlarında kullanılabilir. Verilerin; yazılı, görsel ve işitsel olması farklı örneklem tekniklerine başvurmayı gerektirmektedir.

\subsection{Kayıtlama Yönergesi}

Ampirik yöntem olan sormaca uygulanmasında, sormacanın özelliklerini taşır. Nasıl bir sormacada konu ile ilgili sorular yer alıyor ise, yazı kayıtlama yönergesinde de amaca göre düzenlenmiş sorulara yer verilir. Ancak aradaki fark, yazılım yönergesindeki sorular, insan birimine sorulan ve yanıtı alınarak yazılan soru tiplerinden değildir. Yönergedeki sorular örneklem ile seçilmiş verilere kodlayıcılar tarafından gözlemlenerek işaretlenen bir sormaca biçimidir (Aziz, 2003: 131).

Sorular açık, kapalı, yarı açık uçlu şeklinde sorulacağı gibi şıkları az kapalı uçlu sorular sorulur.

\section{5. Çözümleme}

Çözümleme kodlama kâğıdıyla yapılır. Örneklem sayısına ulaşılıncaya kadar doldurulur. Elde edilen bulgular bilgisayar ortamına aktarılır. Belirli istatistik programları uygulanarak bulgulara ulaşılır.

\section{6. Çıkarsama Yapmak ve Metnin Yazılması}

Birimleştirmelerin yapılmasında, yazılım yönergesinin hazırlanmasında ortaya atılan hususların elde edilen verilerle kanıtlanıp, kanıtlanmadığının belirlenmesidir. Eğer varsayımlara dayalı bir yazılım kayıtlama yönergesi oluşturulmuş ise kanıtlanıp kanıtlanmadığına bakılarak çıkarsamalar yapılabilir. İleri sürülen bir model çoğunlukla kanıtlanmamış ise model de düzeltmeler yapılır. 


\section{2015 Seçim Döneminde 6 Mayıs- 6 Haziran 2015 Tarihleri Arasında Mecliste Grubu Bulunan 4 Partinin Miting Haberlerinin Gazetelerindeki Alan Çözümlemesi}

Bu bölümde, Türk yazılı basınından seçilen Hürriyet, Cumhuriyet, Ortadoğu ve Yeni Şafak gazetelerinden oluşan örneklem üzerinden, 2015 Genel Seçimlerin son 1 ayında (06 Mayıs- 06 Haziran) 4 gazete üzerinden miting haberlerinin alan çözümlemesiyle analiz edilmesi amaçlanmaktadır.

\subsection{Metodoloji}

Araştırma, 2015 Genel Seçimleri öncesinde mecliste bulunan 4 partinin miting haberlerinin gazetelerde eşit fiziki koşullarda verilip verilmediğini araştırmak için Hürriyet, Cumhuriyet, Ortadoğu ve Yeni Şafak Gazetelerinde çıkan miting haberlerinin, içerik çözümleme uygulamalarından, alan analiz uygulamaları yöntemiyle incelenmesini içermektedir. Böylece dört farklı bakış açısına sahip gazetenin farklı partilere eşit söz hakkı verip vermediği aşağıda verilen kodlama cetveli oluşturularak incelenmiştir.

32 Gün boyunca 4 gazete incelenmiştir. Miting haberleri toplanmış ve oluşturulan cetvele işlenmiştir. Ardından çıan haberler " $\mathrm{cm}$ " ile alanları ölçülmüştür. Çıkan sonuçlar yorumlanarak değerlendirme yapılmıştır.

\subsection{1. Çalışmanın Önemi}

Haberler gazetelerde farklı şekillerde ele alınmaktadır. Gazetelerde verilen miting haberleri, daha çok yer kaplayan geniş şekilde verildiğinde, mitinge ilgi çok gibi algılanabilir. Ya da bir partinin yaptığı her miting duyurulduğunda destekçisi diğerlerine göre daha çokmuş gibi algılanabilir. Ya da rakipleri görmezden gelindiğinde alternatifsizmiş gibi algilanabilir. Bütün kamuoyu tek bir partiye odaklanmış gibi düşünülebilir.

Kamuoyu medyaya karşı ön yargılıdır. İktidarı da muhalefeti de medyanın taraflı davrandığını düşünmektedir. 2015 Genel Seçimler öncesi farklı bakış açısına sahip gazetelerin partilere yaklaşımı ne kadar adil, ne kadar demokrattır. Mecliste grubu bulunan partilerin miting haberlerini ne kadar eşit şekilde yayınlamaktadır. Yapılan araştırmayla bu ortaya konmaktadır.

\subsubsection{Sorun}

Medyanın kendi düşüncesine, çıkar ilişkisine veya varoluşsal nedenlere göre belli parti ve ideolojilere ağırlık verirken diğerlerine daha az yer vermekte hatta hiç yer vermemektedir. Bu da medyanın tarafsız olması gerekliliğiyle çatışmakta ve büyük sorun teşkil etmektedir.

\subsubsection{Kapsam ve Sinırlılıklar}

Bugün, Türkiye'de yaklaşık 6800 gazete ve dergi bulunmaktadır (www. byegm.gov.tr). Araştırma evrenindeki yerel ve ulusal gazetelerin çok olması ve araştırmaya konu olan seçim çalışmalarının çok ve yoğun olması, bazı 
sınırlandırmaları zorunlu hale getirmektedir. Seçim çalışmalarının ağırlıklı olarak son bir ay içinde yapılıyor olması nedeniyle, 6 Mayıs - 6 Haziran 2015 tarihleri arasında yayın yapan dört farklı bakış açısını yansıtan Hürriyet, Cumhuriyet, Ortadoğu, Yeni Şafak gazetelerindeki Mecliste grubu olan partiler CHP, MHP, AKP ve HDP'nin miting haberleri incelenecektir.

Seçim döneminde miting haberlerinin yanında milletvekili adaylarının röportajları, adayların bireysel çalışmalarıyla ilgili haberleri de yayınlanmaktadır. Ancak yayınlanan bu haberlerde milletvekili adayları kendisini tanıtma çabası içindedir. Ayrıca adaylar kişisel ilişkilerini kullanarak da medyada yer alabilmektedir. $\mathrm{Bu}$ nedenle parti ikinci planda gözükmektedir. Seçimler öncesi partilerin kurumsal varlığ1 ne kadar medyada görülmektedir? Genel olarak bu çalışmada, partilerin kurumsal kimlikleriyle medya içinde ne kadar yer aldığı miting haberleri üzerinden araştırılmıştır. Bu nedenle partilerin kurumsal kimlikleri en iyi şekilde miting haberlerinde yansitılmaktadır. Kitleler miting haberleriyle partilerin vaatleri, seçim çalışmaları hakkında bilgi sahibi olmaktadır.

\subsubsection{Varsayımlar, Araştırma Soruları}

Basın yayın organları, bir konuyla ilgili haber yaparken, belirli bir kamuoyu oluşturmayı amaçlamaktadır. Bunu da sahip olduğu görüşler ve yayın politikası doğrultusunda, çeşitli söylemler kullanarak yapmaktadır. Varsayımlarımız:

- Gazeteler, her görüşe ve her partiye eşit mesafede değildir.

- Kendilerinin desteklemediği görüşler, partiler eşit şekilde medyada yer almamaktadir.

$\checkmark$ Partilerin; Hürriyet, Cumhuriyet, Ortadoğu ve Yeni Şafak Gazetelerinde çıkan miting haberleri var midır?

$\checkmark$ Çıkan haberlerin kapladığı alan yönünden fark var mıdır?

\subsection{5. Örneklem}

Örneklemimiz Türkiye'de yaklaşık 6800 gazete ve dergi evreni içerisinden olasılıksız (ihtimali olmayan) örnekleme yöntemi ile seçilmiş dört gazetedir. Bunlar Merkezi temsil eden Hürriyet, Merkez Solu ve Solu temsil eden Cumhuriyet, Milliyetçi kesimi temsil eden Ortadoğu, Muhafazakar- Dindar kesimi temsil eden Yeni Şafak gazeteleridir.

\subsubsection{Yöntem}

Sayısal verilerle yorumlar yapabilmek için niteliksel araştırma yöntemlerinden birisi olan içerik analiz uygulamalarından fiziksel alan analizi ile kodlama cetveli oluşturulmuştur. Oluşturulan ilk cetvel 32 gün boyunca 4 gazetede mecliste grubu bulunan partilerin (CHP, MHP, AKP, HDP) haberlerinin varlığıyla ilgilidir. Parti haberi varsa cetvele "VAR" olarak kaydedilmiştir. Partilerin miting haberi yoksa cetvele " $Y$ " olarak kaydedilmiştir. 32 günün sonunda partilerin gazetelerde kaç gün haberleri olduğunu gösteren tablo ve grafik oluşturulmuştur. Daha sonra çıkan haberler cm ile ölçülmüş. Haberlerin kapladığı alanlar $\mathrm{cm}^{2}$ olarak tablolaştırılmıştır. Grafikler oluşturulmuştur. Çıkan sonuç yorumlanmıştır. 


\subsection{Bulgular ve Yorumlar}

\subsubsection{Hürriyet, Cumhuriyet, Ortadoğu ve Yeni Şafak Gazetelerin Miting Haberlerini Verişi}

Dört gazete 06 Mayıs- 06 Haziran 2015 tarihleri arasında 32 gün boyunca takip edilmiştir. $\mathrm{Bu}$ takibin sonunda $\mathrm{AKP}, \mathrm{CHP}, \mathrm{MHP}, \mathrm{HDP}$ 'nin miting haberleri toplanmıştır.

AKP adına Cumhurbaşkanının çalışmaları miting haberleri kapsamında değerlendirilmemiştir. Partilerin milletvekili adaylarının bireysel çalışmaları, röportajları yine bu değerlendirilmeye alınmamıştır. Tablo aşağıdaki gibidir.

32 günün sonunda $\mathrm{AKP}, \mathrm{CHP}, \mathrm{MHP}$, ve $\mathrm{HDP}$ açısından şu verilere ulaşıldı.

Tablo 1. Gazetelerdeki Haber Sayıları

\begin{tabular}{|l|c|c|c|c|c|}
\hline & Hürriyet & Cumhuriyet & Ortadoğu & Yeni Şafak & Toplam \\
\hline AKP & 28 Gün & 20 Gün & 0 Gün & 31 Gün & $128 / 79$ \\
\hline CHP & 28 Gün & 22 Gün & 0 Gün & 2 Gün & $128 / 52$ \\
\hline MHP & 27 Gün & 19 Gün & 32 Gün & 3 Gün & $128 / 81$ \\
\hline HDP & 23 Gün & 19 Gün & 0 Gün & 0 Gün & $128 / 42$ \\
\hline
\end{tabular}

$\mathrm{AKP}, \mathrm{CHP}, \mathrm{MHP}, \mathrm{HDP}$ 'nin miting haberleri aynı günde 4 gazetede, sadece 1 gün yayınlanmamıştır. Diğer günlerde 3 gazetede 3 partinin miting haberi varken diğer gazetede bir partinin miting haberi vardır. Aynı gazetede diğer partilerin miting haberi yoktur. Bir başka günde, iki gazetede miting haberi varken diğer iki gazetede bazı partilerin miting haberi yoktur. Bu nedenle her gazete1 gün olarak alınmıştır. 32 gün, 4 gazete 128 güne denk gelmektedir. 128 günde partilerin miting haberleri kaç günde çıktıysa sayılmıştır. Bu sayım sonucunda şu sonuçlar çıkmıştır.

AKP'nin 128 günde, 79 gün miting haberi yayınlanmıştır. CHP'nin 128 günde, 52 gün miting haberi yayınlanmıştır. MHP'nin 128 günde 81 gün miting haberi yayınlanmıştır. HDP'nin 128 günde 42 gün miting haberi yayınlanmıştır.

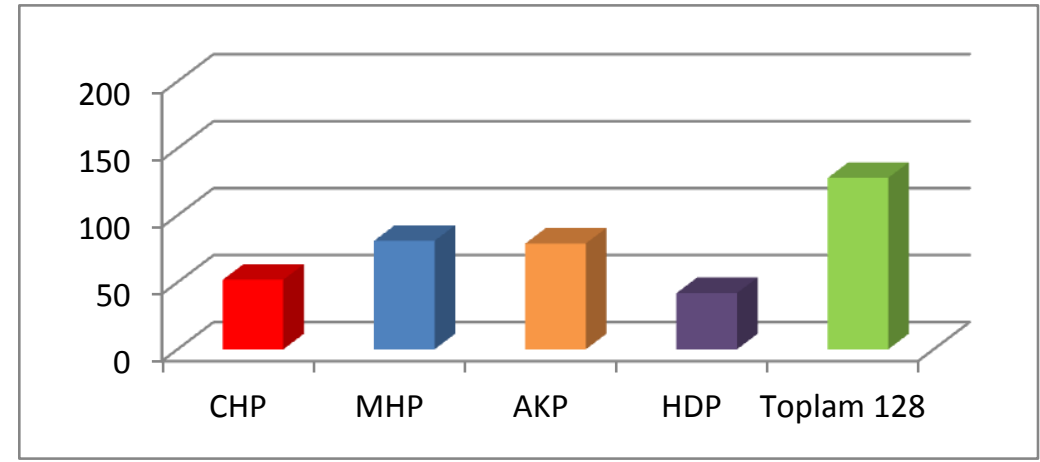

Grafik 1. Gazetelerin Partilere Göre Haber Dağılımı 
Miting haberlerinin verilişine göre MHP birinci, AKP ikinci, CHP üçüncü ve HDP dördüncü olmuştur. MHP'nin birinci olmasında Ortadoğu Gazetesi'nin etkisi fazlasıyla hissedilmektedir. Ortadoğu Gazetesi MHP'nin sesi konumundadır. 32 gün boyunca bütün MHP’nin miting haberlerini vermiştir. Ancak MHP Yeni Şafak Gazetesi'nde 3 gün haber olmuştur.

İkinci olan AKP, Ortadoğu gazetesi dişında bütün gazetelerde yer almıştır. Yeni Şafak Gazetesi'nde 31 gün haber olmuştur. Diğer 1 günü Cumhurbaşkanıyla açılış yaptığı için miting haberi olarak değerlendirilmemiştir.

Üçüncü olan CHP, Ortadoğu Gazetesi'nde hiç haber olmamıştır. Yeni Şafak Gazetesi'nde 2 gün haber olmuştur. CHP, en çok Hürriyet Gazetesi'nde yer bulmuştur. Ardından 22 gün ile Cumhuriyet Gazetesi'nde yer bulmuştur.

Dördüncü olan HDP'nin, muhafazakâr ve milliyetçi kesime yönelik yayın yapan Ortadoğu ve Yeni Şafak Gazetelerinde miting haberleri çıkmamıştır. Miting haberleri en çok Merkezden Hürriyet ve Sol düşünceyi yansıtan Cumhuriyet Gazetelerinde yer bulmuştur.

\subsubsection{Gazetelerin Miting Haberlerini Fiziki Açıdan Verişleri}

Tablo 2. Miting Haberlerini Fiziki Açıdan Verilişleri

\begin{tabular}{|l|l|l|l|l|l|}
\hline & Hürriyet & Cumhuriyet & Ortadoğu & Yeni Şafak & Parti Bazında Toplam \\
\hline CHP & $8110 \mathrm{~cm}^{2}$ & $8534 \mathrm{~cm}^{2}$ & $0 \mathrm{~cm}^{2}$ & $109 \mathrm{~cm}^{2}$ & $16753 \mathrm{~cm}^{2}$ \\
\hline MHP & $8577 \mathrm{~cm}^{2}$ & $4087 \mathrm{~cm}^{2}$ & $96019 \mathrm{~cm}^{2}$ & $492 \mathrm{~cm}^{2}$ & $109175 \mathrm{~cm}^{2}$ \\
\hline AKP & $9280 \mathrm{~cm}^{2}$ & $5335 \mathrm{~cm}^{2}$ & $0 \mathrm{~cm}^{2}$ & $31105 \mathrm{~cm}^{2}$ & $45720 \mathrm{~cm}^{2}$ \\
\hline HDP & $3905 \mathrm{~cm}^{2}$ & $6058 \mathrm{~cm}^{2}$ & $0 \mathrm{~cm}^{2}$ & $0 \mathrm{~cm}^{2}$ & $9963 \mathrm{~cm}^{2}$ \\
\hline Toplam & $29872 \mathrm{~cm}^{2}$ & $24014 \mathrm{~cm}^{2}$ & $96019 \mathrm{~cm}^{2}$ & $31706 \mathrm{~cm}^{2}$ & $181611 \mathrm{~cm}^{2}$ \\
\hline
\end{tabular}

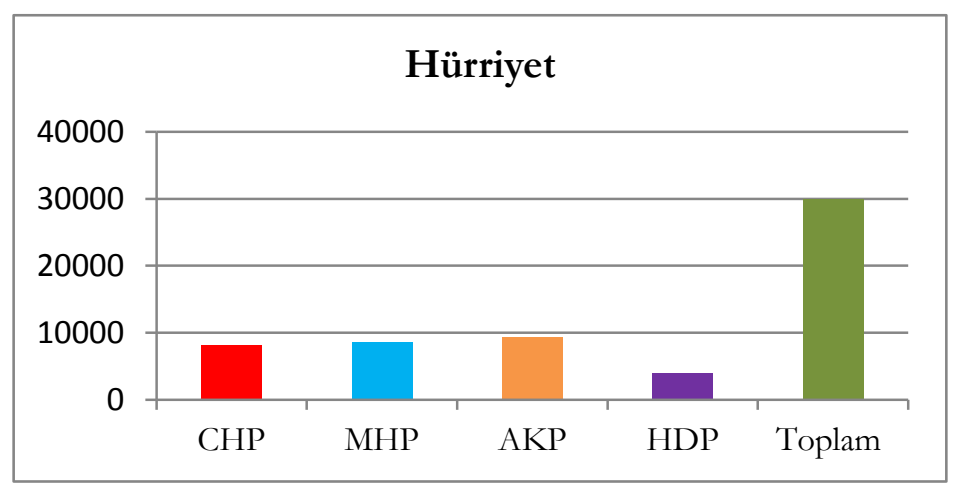

Grafik 2. Haberlerin Partilere Göre Fiziki Dağılımı

Merkezde duran Hürriyet Gazetesi'nde en çok AKP'nin miting haberleri yer almıştır. Birinci olan AKP'nin dışında partilerin miting haberlerinin yer verilişine göre ikinci $\mathrm{MHP}$, üçüncü $\mathrm{CHP}$ ve dördüncü HDP şeklinde sıralanmıştır. Hürriyet Gazetesi'nde AKP mitingleri daha çok ve ayrıntılı yer almıştır. 


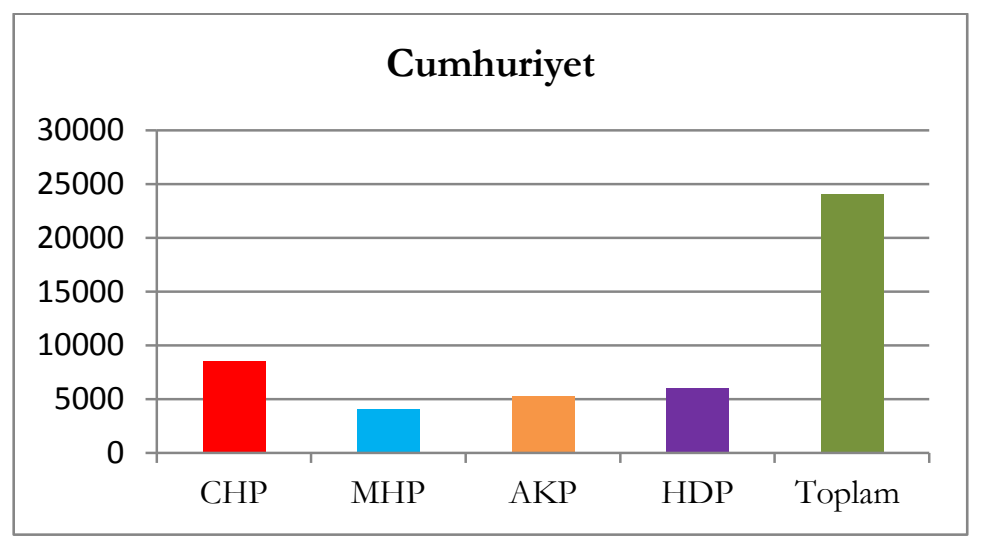

Grafik 3. Cumhuriyet Gazetesindeki Partilerin Haber Dağılımı

$\mathrm{CHP}$ ve HDP, Hürriyet ve Cumhuriyet Gazetelerinde yer bulmuştur. CHP ve HDP; $\mathrm{MHP}$ ve AKP'ye göre Cumhuriyet Gazetesi'nde en çok yer almıştır. Bu da bu gazetenin Sol ideolojiye seslenen yapısından kaynaklanmaktadır.

CHP, merkezde duran Hürriyet'te ve sol bakış açılı Cumhuriyet Gazetelerinde kendine yer bulmuştur. Daha çok Hürriyet'te yer almıştır. HDP, merkez Hürriyet ve merkezin solunda duran Cumhuriyet gazetelerinde vardır. HDP'nin miting haberleri en çok Cumhuriyet Gazetesi'nde yer bulmuştur. İkinci sırada Hürriyet Gazetesi'nde yer bulmuştur.

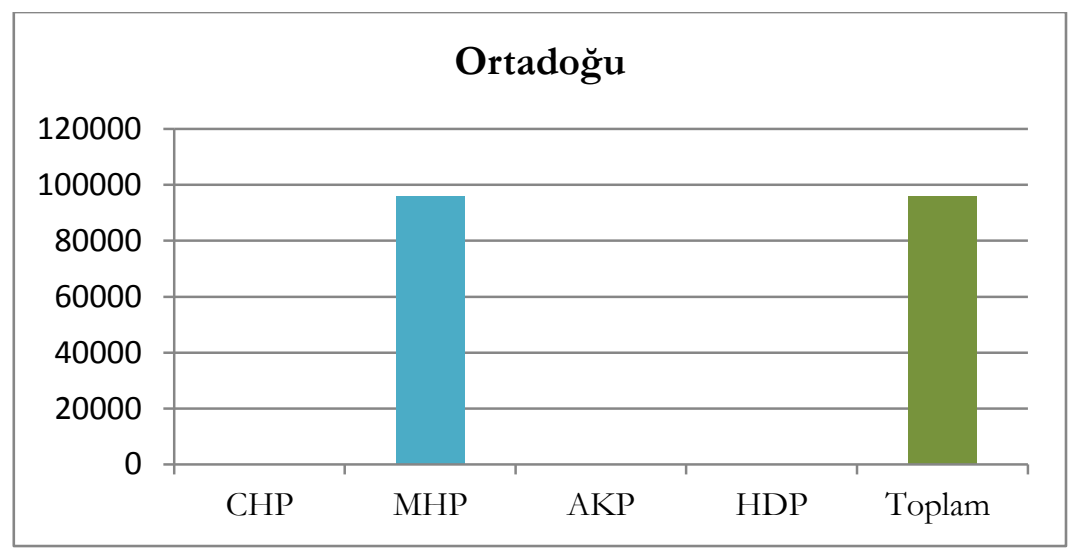

Grafik 4. Ortadoğu Gazetesindeki Partilerin Haber Dağılımı

Alansal açıdan gazeteler ideolojik yaklaşımlarına göre partilere yer vermiştir. Alansal açıdan Ortadoğu Gazetesi'nde en fazla ayrıntı alan parti MHP'dir. Ortadoğu Gazetesi'nde aldığı $96019 \mathrm{~cm}^{2}$ alan bunda etkili olmuştur. MHP'nin haberleri en çok Ortadoğu Gazetesi'nde yer almaktadır. Ortadoğu Gazetesi'nde AKP hiç yer almamıştır. Ortadoğu MHP'nin sesi olduğundan, CHP, AKP ve HDP yoktur. 


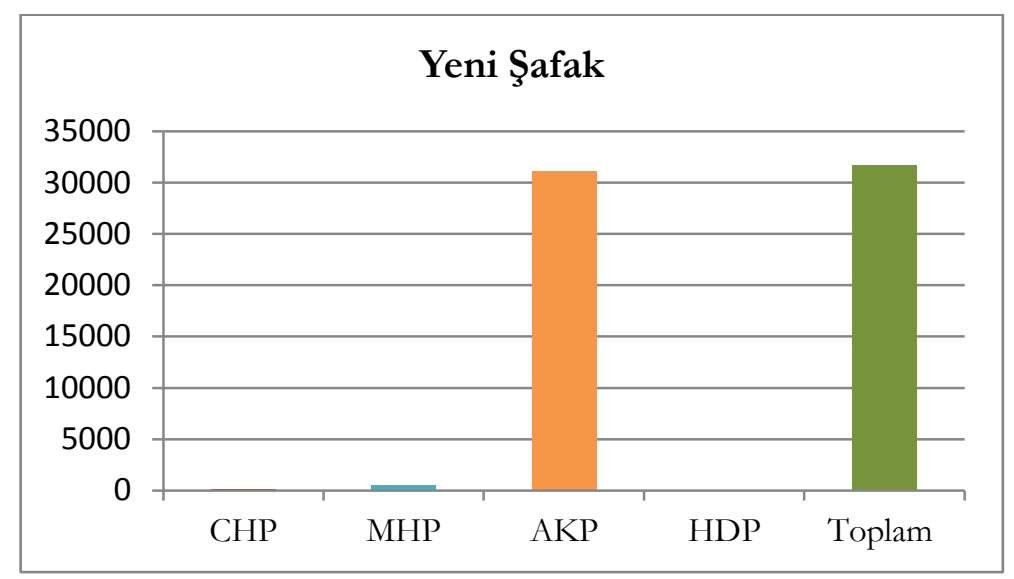

Grafik 5. Yeni Şafak Gazetesindeki Partilerin Haber Dağılımı

Yeni Şafak Gazetesi ideolojik yapısını gazeteye yansıtmaktadır. En fazla payı AKP'ye vermiştir. Daha sonra $492 \mathrm{~cm}^{2} \mathrm{MHP}$ 'ye ve $109 \mathrm{~cm}^{2} \mathrm{CHP}^{\prime}$ ye yer ayırmıştır. AKP açısından miting haberlerini en fazla Yeni Şafak Gazetesi yer vermiştir. MHP Muhafazakâr, dindarların sesi olan Yeni Şafak Gazetesi'nde 3 gün yer almıştır. Yeni Şafak da iktidar yanlısı muhafazakâr olduğu için CHP 2 gün yer bulabilmiştir. Yeni Şafak Gazetesi'nde HDP'ye ise hiç yer verilmemiştir.

HDP, Ortadoğu ve Yeni Şafak gazetelerinde hiç yoktur. Muhafazakâr ve Milliyetçi kesimin okuduğu gazetelerde bulunmaması normaldir.

Mitinglerin verilişine göre en çok yayınlanan MHP'dir. Ardından AKP gelmektedir. MHP'nin birinci olmasında Ortadoğu'nun var gücüyle MHP'yi anlatması, diğer partileri anlatmaması yatar. Bu da MHP'nin oranlarını arttırmıştır. Üçüncü parti olarak CHP gelmektedir. Ortadoğu gazetesinde yoktur. Yeni Şafak Gazetesi'nde 2 gün miting haberi yayınlanmıştır. HDP ise bütün oranlarını Hürriyet ve Cumhuriyet gazetelerinden sağlamıştır. HDP'nin, Hürriyet ve Cumhuriyet gazetelerinde miting haberleri yayınlanmıştır.

\section{SONUÇ VE DEĞERLENDİRME}

$\mathrm{Bu}$ çalışma ile gazetelerin farklı görüşlere nasıl yaklaştıklarını göstermektedir. Farklı ideolojileri destekleyen 4 farklı gazete merkezde durduğunu iddia eden Hürriyet, Sol görüşleri yansıtan Cumhuriyet, Milliyetçilerin takip ettiği Ortadoğu ve iktidar destekçisi muhafazakârların tercih ettiği Yeni Şafak bunun için örneklem seçildi.

Seçim döneminde miting haberlerinin yanında milletvekili adaylarının röportajları, adayların bireysel çalışmalarıyla ilgili özel haberler yayınlanmaktadır. Ancak yayınlanan bu haberlerde milletvekili adayları, aday olduğu bölge seçmenine kendisini tanıtma çabası içindedir. Ayrıca adaylar kişisel ilişkilerini kullanarak da medyada yer alabilmektedir. Ya da aday popüler kişiliktir. Bu adayın haberleri yine partinin önüne geçmektedir. Bu nedenle parti ikinci planda kalmaktadır. Bu nedenle partilerin kurumsal kimlikleri en iyi şekilde miting haberlerinde yansitılmaktadır. 
Kitleler miting haberleriyle partilerin vaatleri, seçim çalışmaları hakkında bilgi sahibi olmaktadir.

Çıkan sonuçları daha iyi analiz etmek için bir önceki seçim olan 2011 Genel Seçim Sonuçları ile 2015 Genel Seçim sonuçlarına bakmakta fayda vardır. 2011 ve 2015 Genel Seçim sonuçları aşağıdaki grafiklerdeki gibidir.

Tablo 3. Türkiye Genel Seçim Sonuçları

\begin{tabular}{|l|c|c|}
\hline \multicolumn{1}{|c|}{ PARTILER } & 2011 Seçim Sonuçları & 2015 Seçim Sonuçları \\
\hline AKP & $49,95 \%$ & $40,87 \%$ \\
\hline CHP & $25,94 \%$ & $24,95 \%$ \\
\hline MHP & $12,98 \%$ & $16,29 \%$ \\
\hline Bağımsızlar / HDP & $6,68 \%$ & $13,12 \%$ \\
\hline
\end{tabular}

İlk bakışta 2011'de Bağımsız olarak seçime giren ve \% 6,68 oy alan HDP, 2015 Genel Seçimlerinde \% 13,12 oy alarak bir çıkış yapmıştır. 2. Olarak aldığı oy olarak MHP oylarını arttırmıştır. CHP oylarını korumuştur. AKP ise hem oylarında hem de yüzdelik oranlarda büyük bir düşüş içerisindedir.

$\mathrm{Bu}$ çalışma gösterdi ki Hürriyet; 32 gün boyunca $\mathrm{CHP}^{\prime}$ ye 28, AKP'ye 28, MHP'ye 27 ve $\mathrm{HDP}^{\prime}$ ye 23 gün miting haberleri yapmıştır. En çok miting haberi yapan gazetedir. Hürriyet; CHP'ye $8110 \mathrm{~cm}^{2}$, MHP $8577 \mathrm{~cm}^{2}$, AKP $9280 \mathrm{~cm}^{2}$, HDP $3905 \mathrm{~cm}^{2}$ sayfalarında miting haberlerine yer ayırmıştır. Mecliste grubu bulunan 4 partinin miting haberini yayınlamıştır. Ancak iktidar olan AKP'nin haberleri fiziki açıdan diğer partilerden daha çoktur. HDP Hürriyet'te de en az miting haberi yapılan partidir. Bu olumsuzluklara rağmen mecliste grubu bulunan partilerin miting haberlerine yer vermesi nedeniyle diğer 3 gazete içerisinde Hürriyet en demokrat gazete gözükmektedir.

Ortadoğu Gazetesi demokratik açıdan en gerideki gazetedir. Sadece MHP’nin miting haberleri vardır. Sadece MHP'nin sesi olmuştur. 32 gün boyunca sadece MHP'nin miting haberlerine yer vermiştir. Ortadoğu Gazetesi'nde MHP'ye 96019 cm$^{2}$ yer ayrılmıştır. Bu yüksek değer, MHP’nin bu araştırmadaki sonuçlarını da etkilemiştir. Normalde olduğundan daha yüksek göstermiştir. Bu sonuçla medyada miting haberlerine en çok yer ayrılan partidir. Seçim sonuçlarına baktığımızda da oylarını hem yüzdelik anlamında hem de oy sayısı anlamında arttırmıştır. Ancak meclisteki partilere yaklaşım açısından demokrat tutum noktasında bu araştırma kapsamında 4 gazete içinde sonuncu durumundadır.

Yeni Şafak Gazetesi, AKP destekleyen bir yayın çizgisine sahiptir. Yeni Şafak; 32 gün boyunca, 31 gün $\mathrm{AKP}$ 'nin, 3 gün $\mathrm{MHP}$ nin, 2 gün de $\mathrm{CHP}^{\prime}$ nin miting haberlerine yer vermiştir. HDP'nin mitinglerini görmezden gelmiştir. AKP'ye 31105 $\mathrm{cm}^{2}$ yer ayırmıştır. CHP'ye $109 \mathrm{~cm}^{2}$, MHP'ye $492 \mathrm{~cm}^{2}$ yer vermiştir. Demokratlıkta 3 . sıradadır. MHP ve CHP'ye yönelik haberlerin yayınlanan alan açısından AKP'nin çok 
gerisindedir. Ortadoğu Gazetesi'nin MHP'nin parti gazetesi olması, Yeni Şafak Gazetesi' nin bu antidemokratik yayın anlayışını yumuşatmaktadır.

Cumhuriyet gazetesi de genellikle muhalefet partilerine ağırlık vermiştir. CHP ve HDP ağırlıklı bir yayın almayışına sahiptir. Üçüncü olarak AKP, sonuncu olarak MHP gözükmektedir.

Mecliste grubu bulunan partilerin miting haberlerini demokratik yönden veriş sırasına göre birinci Hürriyet, ikinci Cumhuriyet, üçüncü Yeni Şafak, son sırada dördüncü olan Ortadoğu Gazetesi' dir.

Hürriyet, Cumhuriyet, Ortadoğu ve Yeni Şafak gazetelerinde 32 günün sonunda $181611 \mathrm{~cm}^{2}$ miting haberleri yapılmıştır. CHP, MHP, AKP ve HDP'nin miting haberlerinin 4 gazetede kapladığı alan açısından değerlendirdiğimizde, MHP, 109175 $\mathrm{cm}^{2}$ ile birinci partidir. İkinci parti $45720 \mathrm{~cm}^{2}$ lik miting haberi yapılan AKP'dir. CHP'nin miting haberleri $16753 \mathrm{~cm}^{2}$ lik yer alarak üçüncü partidir. Medyada en az yer alan parti $9963 \mathrm{~cm}^{2}$ lik alanda miting haberleri çıkan HDP' dir.

Seçim sonuçlarıyla kıyasladığımızda HDP'nin 4. Parti olmasıyla örtüşmektedir. HDP oylarını arttırmıştır. Ancak, HDP 2011 Genel Seçimlerine parti olarak değil, bağımsız adaylar üzerinden seçime girdiğinden parti bazında buradaki değerlendirmeye girmemektedir. MHP seçimlerde bir önceki 2011 seçimlerine göre 2 milyon oyunu arttırmıştır. AKP, 4 gazete içinde miting haberleri açısından ikinci sırada kalmıştır. 2011 Genel Seçimlerine göre oyları düşmüştür. CHP, miting haberlerinin yer alışına göre 3. Partidir. Seçim sonuçlarına göre oylarını korumuştur. Muhafazakâr Yeni Şafak Gazetesi'nde 2 gün yer almıştır. Milliyetçi Ortadoğu Gazetesi'nde hiç yer alamamıştır. Sesini daha geniş kitlelere duyuramamıştır. 2011 seçimlerinde aldığı sonuçla, 2015 seçimlerinde aldığı sonuç hemen hemen örtüşmektedir, aynıdır.

$\mathrm{Bu}$ çalışma göstermiştir ki gazeteler yakın olduğu, benimsediği ideolojinin etkisi altındadır. Ortadoğu, MHP'nin, Yeni Şafak AKP'nin, Cumhuriyet CHP ve HDP'nin miting haberlerine ağırlık vermiştir. 


\section{KAYNAKÇA}

Aziz, Aysel (2003) Araştırma Yöntemleri ve Teknikleri ve İletişim, Ankara: Turhan Kitabevi.

Balcı, Ali (2011) Sosyal Bilimlerde Araştırma Yöntem, Teknik ve İlkeleri, Ankara: PEGEM Akademi Yayınları

http://dergiler.ankara.edu.tr/dergiler/40/506/6144.pdf (05.06.2015)

http://sbd.ogu.edu.tr/makaleler/7133911_1_Makale_14.pdf (06.06.2015)

http://www.byegm.gov.tr/uploads/docs/Bir_Bakista_Turk_Medyasi_TR.pdf (06.06.2015)

http://www.hurriyet.com.tr/secim2011/default.html (23.06.2015)

http://secim.haberler.com/2015/ (23.06.2015)

Cumhuriyet Gazetesi,

Hürriyet Gazetesi,

Ortadoğu Gazetesi,

Yeni Şafak Gazetesi, 